\title{
POCZĄTKI PARAFII MATKI BOŻEJ KRÓLOWEJ KORONY POLSKIEJ W BARANOWICZACH POLESKICH NA PODSTAWIE KSIĘGI INWENTARZOWEJ PARAFII BARANOWICZE Z 2 MAJA 1938 ROKU
}

Polskie miasto kresowe Baranowicze, w województwie nowogródzkim, od 1991 roku miasto na Białorusi, w obwodzie brzeskim, w którym mieści się siedziba władz rejonu (powiatu). Współcześnie liczy 168,2 tys. mieszkańców (2010) i stanowi ośrodek przemysłu metalowego i włókiennictwa

Pierwsza wzmianka o miejscowości Baranowicze pochodzi z 1709 roku. W drugiej połowie XIX wieku była własności hrabiny Rozwadowskiej (prawosławnej) i jej męża Jana (Polaka i katolika). Budowa linii kolejowej Brześć - Moskwa i Równe-Wilno spowodowała rozwój gospodarczy osady założonej w związ$\mathrm{ku} \mathrm{z}$ tą inwestycją zapoczątkowaną w 1870 roku. W tym roku Baranowicze liczyły 4 tysiące mieszkańców i stanowiły ważny węzeł kolejowy - tzw. koleje poleskie, które były silnym czynnikiem miastotwórczym. Prawa miejskie Baranowicze uzyskały za czasów II Rzeczypospolitej - w 1919 roku. Po traktacie ryskim miasto pozostało w granicach Polski do 17 IX 1939 roku. Zamieszkiwała je ludność polska, białoruska i żydowska. Pod koniec lat trzydziestych XX wieku Baranowicze były największym miastem i głównym centrum komunikacyjnym województwa nowogródzkiego. W okresie międzywojennym w mieście istniał, drugi po warszawskim Grób Nieznanego Żołnierza. W Baranowiczach mieściła się siedziba garnizonu wojskowego liczącego trzy tysiące osób (1928) oraz oddział Korpusu Ochrony Pogranicza ${ }^{1}$. W mieście stacjonowała Nowogródzka Brygada Kawalerii,

* Ks. Waldemar W. Żurek - dr hab. historii Kościoła, dyrektor Ośrodka Archiwów Bibliotek i Muzeów Kościelnych KUL.

${ }^{1} \mathrm{KOP}$ - formacja wojskowa przeznaczona dla ochrony wschodniej granicy Polski ze Związkiem Radzieckim, z Litwą (od XI 1924), Łotwą (od III 1926), z Węgrami (od wiosny 1939), częściowo z Rumunią (113 km) i Prusami Wschodnimi $(73 \mathrm{~km})$, dla zapewnienia i ugruntowania bezpieczeństwa publicznego oraz zwalczania działalności antypaństwowej. Działał w pasie granicznym ok. $30 \mathrm{~km}$. KOP prowadził również prace społeczno-gospodarcze i podejmował inicjatywy kulturalno-oświatowe. Dnia 1 IX 1939 r. podjął walkę z Niemcami, a od 17 września tego roku z Armią 
którą od 1937 roku dowodził gen. Władysław Anders. Działała tu od 1938 roku trzecia, po wileńskiej i lwowskiej, radiostacja Polskiego Radia na Kresach (Polskie Radio Baranowicze). Pod względem administracji kościelnej miasto leżało w granicach dekanatu Baranowicze w diecezji pińskiej, utworzonej w 1925 roku$^{2}$.

Potrzebę utworzenia parafii rzymskokatolickiej w Baranowiczach Poleskich odczuwano od początku XX wieku. W miarę rozwoju miasta, które stało się ośrodkiem przemysłu i handlu, ks. kanonik Lucjan Żołądkiewicz wybudował z pomocą parafian w 1925 roku kaplicę drewnianą pw. Podwyższenia Świętego Krzyża przy ulicy Narutowicza 78. Jej poświęcenia w tym samym roku dokonał biskup piński Zygmunt Łoziński. Od tego roku datuje się utworzenie w Baranowiczach parafii ${ }^{3}$. W miarę rozwoju miasta i wzrostu liczby jego mieszkańców erygowana parafia nie zaspokajała $\mathrm{w}$ stopniu wystarczającym potrzeb tamtejszych wiernych. Dla potrzeb religijnych stacjonujących w Baranowiczach kilku pułków wojskowych służył kościół garnizonowy pw. św. Antoniego Padewskiego (proboszcz ks. Antoni Aleksandrowicz - 19374), z którego korzystali także miejscowi wierni.

Czerwoną oraz bitwy z oddziałami sowieckimi. Garnizon Baranowicze został podporządkowany Dowództwu Korpusu okręgu Brześć nad Bugiem (dowódca gen. Kleeberg). Stacjonowały w nim: bataliony wchodzące w skład 20 Dywizji Piechoty, część batalionów 44 Pułk Strzelców Legii Amerykańskiej (sformowany w 1918 r. we Francji), sztab Brygady Kawalerii Baranowicze (1 IX 1937 przemianowana w Nowogródzką Brygadę Kawalerii), 1 i 4 dywizjon 20 Pułk Artylerii Lekkiej. M. Cieplewicz, Korpus Ochrony Pogranicza, w: Historii Drugiej Rzeczypospolitej, red. A. Garlicki, Warszawa 1999, s. 171; H. Dominiczak, Granica wschodnia Rzeczypospolitej Polskiej w latach 1919-1939, Warszawa 1992, s. 102-128; kielakowie.pl/tng/histories/baranowicze.php (odczyt 22 IV 2012).

${ }^{2}$ Baranowicze, w: Encyklopedia Kresów, Wydawnictwo Kluszczyński, Kraków 2004, s. 27.

${ }^{3}$ Kościół pw. Podwyższenia Krzyża Świętego w czasach II Rzeczypospolitej i ZSRR stanowił główny ośrodek tamtejszych Polaków. Był nieprzerwanie czynny w okresie komunizmu sowieckiego, zachowany do dnia dzisiejszego. Spis kościołów i duchowieństwa diecezji pińskiej w R. P. 1937. Stan diecezji na dzień 27 lutego 1937 roku, Pińsk 1937, s. 49.

${ }^{4}$ Ks. Aleksandrowicz Antoni, mjr (1893-1940); święcenia kapłańskie otrzymał w 1916 roku w Petersburgu. W 1919 roku. był katechetą w Mińsku; w korpusie duszpasterskim Wojska Polskiego od 1919; do 1920 był kapelanem do zleceń przy Duszpasterstwie Rzymskokatolickim 4 armii. W 1928 roku został proboszczem parafii wojskowej Słonim a następnie administratorem parafii wojskowej w Baranowiczach; we wrześniu 1939 ranny w nogę; więziony w Kozielsku i zamordowany przez NKWD. Borowski E., Martyrologium duchowieństwa diecezji pińskiej w latach 1939-1956, w: Martyrologium duchowieństwa polskiego 1936-1956, Łódź, s. 113. 
Pierwotnie Baranowicze należały do dwóch parafii. Południowa część miasta należała do parafii w Nowej Myszy ${ }^{5}$, a północna do parafii Darewo ${ }^{6}$. W przeszłości wyżej wymienione części Baranowicz przedzielone były gęstym lasem i terenem trudnym do przebycia. Po erygowaniu w tym mieście parafii dotychczasowe dwie dzielnice miasta znalazły się w granicach utworzonej parafii. Jednak znaczna odległość mieszkańców okolicznych miejscowości od kościoła parafialnego i wzrost liczby mieszkańców miasta mobilizowała tamtejszych katolików do starań o utworzenie kolejnej placówki duszpasterskiej w tym mieście. Wprawdzie wierni uczestniczyli $\mathrm{w}$ nabożeństwach $\mathrm{w}$ parafialnym kościele garnizonowym, znacznie bliżej położonym od parafialnego, jednak nabożeństwa tam odprawiane były w godzinach niedogodnych dla ludności cywilnej. Stąd mieszkańcy Baranowicz Poleskich wielokrotnie zwracali się z prośbą do biskupa pińskiego o utworzenie w ich mieście kolejnej placówki duszpasterskiej.

Starania pasterza diecezji i wiernych o nowy ośrodek duszpasterski w Baranowiczach spotęgowali tamtejsi baptyści, którzy utworzyli w tym mieście dwa punkty modlitwy: przy ulicy Żwirki i ulicy Szarowej. Ich aktywność mobilizowała katolików do intensywniejszych wysiłków zmierzających do utworzenia kolejnej parafii katolickiej w mieście i budowy kościoła. Głównym problemem biednej i zaniedbanej dzielnicy Baranowicz, gdzie planowano utworzenie nowej parafii, był brak odpowiedniego budynku na sprawowanie służby Bożej.

Biskup piński ks. Kazimierz Bukraba7 skierował dnia 24 IX 1936 roku pismo do ks. Antoniego Kohutnickiego ${ }^{8}$, informując go, iż zostało mu powierzone zada-

\footnotetext{
${ }^{5}$ Świątynia parafialna pw. Przemienienia Pańskiego w Nowej Myszy, murowana, wybudowana w 1824 roku, ufundowana przez Sapiehów. Spis kościołów i duchowieństwa diecezji pińskiej w R.P. 1939, Pińsk 1939, s. 53.

${ }^{6}$ Kościół parafialny pw. Wniebowzięcia N.M. P w Darewie w czasie wojny w 1915 roku został zburzony. Nowy murowany, wybudowany w 1937 roku z ofiar parafian, przez proboszcza ks. Stanisława Szaplewicza, konsekrowany dnia 15 VIII 1938 roku przez bpa Kazimierza Bukrabę. Spis kościołów i duchowieństwa diecezji pińskiej w R. P. 1939, s. 51.

${ }^{7}$ Kazimierz Bukraba, ur. 23 XI 1885 roku w Grodnie. Wyświęcony na kapłana 2 II 1909 roku w Krakowie. Mianowany biskupem pińskim 10 VII 1932 roku. Konsekrowany 21 VIII 1932 roku w Wilnie. Objął rządy diecezją 28 VIII 1932 roku. Był drugim ordynariuszem diecezji pińskiej, po zmarłym w 1932 roku biskupie Zygmuncie z Łozin-Łozińskim (1925-1932). W 1934 roku ogłosił statuty synodu diecezjalnego, kilkakrotnie wizytował diecezję, rozbudował sieć parafialną i utworzył 2 nowe dekanaty, sprowadził do pracy w diecezji jezuitów, Marianów, werbistów oraz urszulanki szare. W 1939 roku wyjechał do Lwowa, stamtąd do Warszawy, zmarł 7 V 1946 roku w Łodzi. A. Petrani, Bukraba Kazimierz, EK, t. 2, Lublin 1985, k. 1189, 1190.

${ }^{8}$ Kohutnicki Antoni, kapłan diecezji kamienieckiej, ur. 1887 roku na Wołyniu, maturę zdał w 1907 roku w Żytomierzu, w 1909 wstąpił do seminarium duchownego w Żytomierzu, które ukończył w 1914 roku święceniami kapłańskimi z rąk biskupa pomocniczego Longina Żarnowieckiego. Pracował w parafii Toporyszcze, Krzemieńcu, Kutkowce na Podolu (proboszcz), Czercze w dekanacie kamienieckim (proboszcz), skąd w połowie 1920 roku opuścił Podole i wyjechał do Polski. Tu pracował w diecezji kieleckiej (Rakoszyn od IV do IX 1925), w diecezji podlaskiej (Dołhobrody). W 1930 roku po ekskardynowaniu z diecezji kamienieckiej wyjechał do pracy wśród emigracji polskiej we Francji, skąd po kilku miesiącach powrócił, przenosząc się do diecezji wileńskiej. Tu pracował w parafii w Giełczynie (1931-1932), Bielicy (1932-1934), Balingródku (od 1935-kilka miesięcy), Dąbrowa. W 1936 roku przeniósł się do diecezji pińskiej. Po II wojnie światowej wyjechał
} 
nie organizowania od 1 października tego roku kolejnej parafii w Baranowiczach, z podjęciem od wiosny 1937 roku budowy kościoła pw. Matki Bożej Królowej Korony Polskiej ${ }^{9}$. Ks. Kohutnicki przybył do Baranowicz już dnia następnego i podjął zadania zlecone mu przez pasterza diecezji. Zamieszkał tymczasowo u swego brata, dowódcy brygady Korpusu Ochrony Pogranicza - pułkownika Romualda Kohutnickiego (wojskowe koszary im. Tadeusza Kościuszki) i rozpoczął poszukiwania odpowiedniego terenu w mieście pod lokalizację przyszłego kościoła. Od początku spotykał się z obojętnością biednych i bezrobotnych mieszkańców polskiego miasta kresowego. Planowi powstania kolejnej parafii w Baranowiczach przeciwny był tamtejszy (od 1933 roku) dziekan i proboszcz parafii Podwyższenia Świętego Krzyża - ks. Jan Borysiuk ${ }^{10}$, niechętny idei podziału dotychczasowej parafii w tym mieście i jej przyszłemu proboszczowi - ks. Antoniemu Kohutnickiemu.

Pierwotnie ks. Kohutnicki zdecydował o budowie prowizorycznej kaplicy na terenie położonym wokół ulic: Mickiewicza, Kosynierów i Kochanowskiego. Na ten cel nabył przy ul. Mickiewicza plac z domem gdzie rozpoczął gromadzenie materiałów budowlanych. W przejętym budynku umieścił szaty liturgiczne, paramenty kościelne oraz meble otrzymane z Kurii Biskupiej w Pińsku dla powstającej parafii w Baranowiczach; m.in. ławki, obrazy. Budowie kaplicy w tej części miasta sprzeciwili się niektórzy członkowie zdekompletowanego społecznego ko-

na Ziemie Odzyskane, gdzie od 1 IX 1945 do 15 XII 1959 roku był proboszczem parafii Łęgowo w diecezji gdańskiej. Zmarł 27 IV 1971 roku na terenie tej diecezji. Catalogus ecclesiarum et cleri Archidioecesis Vilnensis. Pro Anno Domini 1933-1936, Vilnae 1933-1936; W. Rosowski, Dzieje rzymskokatolickiej diecezji kamienieckiej w latach 1918-1941, Lublin 2008, s. 160.

${ }^{9}$ Archiwum Diecezjalne w Drohiczynie (dalej: ADD), Zespół: Archiwum Parafii Baranowicze (Sygn. III/J/), Delegacja bpa K. Bukraby dla ks. A. Kohutnickiego na organizowanie nowej parafii i budowy kościoła z 24 IX 1936 (L. 4036/36) - Pińsk.

${ }^{10}$ Borysiuk Jan Kazimierz, kapłan diecezji kamienieckiej. Ur. 1888, gimnazjum ukończył w Brześciu Litewskim, seminarium duchowne w Żytomierzu, gdzie w 1911 roku przyjął święcenia kapłańskie z rąk bpa L. Żarnowieckiego.Po święceniach pracował w parafii katedralnej w Kamieńcu Podolskim jako katecheta. Organizator harcerstwa męskiego i żeńskiego w tym mieście oraz opiekun miejscowego sierocińca, w połowie 1920 roku proboszcz parafii Letniowce (dek. uszycki). W czasie wojny polsko-bolszewickiej (1918-1920) przeniósł się do diecezji wileńskiej. W 1922 roku objął stanowisko kapelana wojskowego Szpitala Okręgowego nr IX w Brześciu n. Bugiem - do 1925. W tym czasie pracował także w ZHP i PCK jako kapelan. Po przeniesieniu do rezerwy pozostał w nowo powstałej diecezji pińskiej, zachowując jednak przynależność do diecezji kamienieckiej. W latach 1927-1933 katecheta gimnazjum w Brześciu, od 1933 roku mianowany proboszczem i dziekanem w Baranowiczach przy parafii Podwyższenia Krzyża Świętego. Równocześnie pełnił obowiązki dziekana lachowickiego (parafia Lachowicze). W czasie II wojny światowej opiekował się parafią Nowa Mysz (1943-1944). W latach 1945-1947 był wikariuszem generalnym diecezji pińskiej i kierował nią z zastępstwie nieobecnego biskupa. Aresztowany przez agentów MGB w Baranowiczach w 1948, skazany na 10 lat łagrów i skierowany do Sibłagu k. Nowosybirska. W maju 1950 roku wysłany do Omłagu k. Omska na Syberii, gdzie zmarł w 1953 roku. Nieznana jest dokładna data jego śmierci (może w Workucie). Elenchus ... Camenecensis, 1924, s. 18, 20; R. Dzwonkowski, Leksykon duchowieństwa polskiego represjonowanego w ZSRR 1939-1988, Lublin 2003, s. 137-138; Kresowi księża harcerze od Kamieńca Podolskiego do Nowogródka. Wspomnienia, opr. H. Dąbkowski, Warszawa 1999, s. 34-36. 
mitetu budowy wcześniejszego kościoła parafialnego w tym mieście ${ }^{11}$. Do ówczesnych przeciwników tej idei należeli m.in. Kotłobaj, generał Skotnicki oraz starosta baranowicki Karol Wańkowicz ${ }^{12}$. Byli oni zdania, że nie powinno się tworzyć tymczasowych prowizoriów. Jednak przedstawiane przez przeciwników argumenty były nieracjonalne. Jest normalną praktyką pastoralną, iż przy organizowaniu nowej parafii i podejmowaniu budowy kościoła, dla wiernych udostępnia się tymczasową kaplicę do sprawowania nabożeństw i tworzenia nowej wspólnoty parafialnej. Chyba że wyżej wymienieni mieli inne powody aby udaremniać plany zorganizowania kolejnej parafii w tym mieście.

W związku z powyższym, aby nie pogłębiać rozdźwięku we współpracy z niektórymi członkami byłego komitetu i nadal wpływowymi w tamtejszej społeczności, ks. Kohutnicki odstąpił od projektu budowy tymczasowej kaplicy na wybranym miejscu. W celu bliższego poznania swoich parafian przyszły proboszcz odwiedzał ich domostwa, a w czasie takich wizyt uwrażliwiał swoich rozmówców na potrzebę nabycia innej parceli i odpowiedniego lokalu na urządzenie w nim prowizorycznej kaplicy, co wkrótce udało się zrealizować. Zakupiono budynek drewniany przy ulicy Rynkowej 24, w którym po przeprowadzeniu prac adaptacyjnych otwarto tymczasową kaplicę dla przyszłej parafii Królowej Korony Polskiej. Jej poświęcenia dokonał dnia 13 XI 1936 roku kanclerz Kurii Diecezjalnej w Pińsku, ksiądz kanonik Bronisław Kiełbassa w asyście księdza prałata ks. Lucjana Chwiećki ${ }^{13}$, kierownika Wydziału Gospodarczego Kurii Diecezjalnej

${ }^{11}$ Społeczny komitet budowy kościoła w Baranowiczach powstał przed I wojną światową, dla utworzenia w tym mieście parafii. Jego członkowie udali się w delegacji do księdza abpa Wincentego Kluczyńskiego w Petersburgu o przydzielenie do pracy duszpasterskiej w Baranowiczach księdza. ADD, Zespół: Archiwum Parafii Baranowicze (Sygn. III/J), Podanie Adolfa Szczuka z Baranowicz do ordynariusza pińskiego z 2 VIII 1939 - Baranowicze.

${ }^{12}$ Wańkowicz Karol, starosta baranowicki, właściciel majątku i dworu Mikielewszczyzna (obecnie Michelewszczyzna), w prostej linii potomek znanego malarza Walerego Wańkowicza (1799-1842), a daleki krewny pisarza Melchiora (1892-1973). Urodził się 4 XI 1894 w Warszawie, ożenił się 4 II 1923 w Warszawie z Kazimierą Teresą Römer, zmarł 18 XII 1990 w domu Antokol koło Londynu.

Patrityczną postawę okazał starosta Wańkowicz po agresji wojsk sowieckich na Polskę 17 IX 1939, w czasie rabunku przez sowietów zasobów finansowych i depozytów, w tym złota i kosztowności, które były w posiadaniu instytucji państwowych, banków, osób prywatnych i kościołów. Nie mając czasu ani środków na przeprowadzenie zorganizowanej ewakuacji Baranowicz, zaalarmował poprzez gminy najbardziej narażonych przedstawicieli ludności polskiej: ziemiaństwo, osadników, nauczycieli i parafie. Zorganizował opiekę nad pozostałymi w mieście urzędnikami i rodzinami ewakuowanych oraz zapewnił im na jakiś czas pomoc pieniężną. Ponadto podjął z Banku Polskiego i zabezpieczył pieniądze i inne katywa, aby nie wpadły w ręce sowietów. www.historia/kresy.html; www.geni.com/people (odczyt 15 V 2012).

${ }^{13}$ Chwiećko Lucjan, ur. w 1889 w Małyszewie (gub. grodzieńska), ukończył Seminarium Duchowne i Akademię Duchowną w Petersburgu, w 1914 roku otrzymał święcenia kapłańskie. Był wykładowcą liturgiki w seminarium, a po jego likwidacji w 1918 roku został mianowany wikariuszem w Petersburgu. Wspólnie z ks. Fabianem Abrantowiczem (1884-1939) założyli białoruskie Chrześcijańskie Zjednoczenie Demokratyczne. Aresztowany 10 III 1923 roku stanął przed sądem w „procesie 14” i otrzymał wyrok 10 lat więzienia. Drogą wymiany więźniów polsko-radzieckich z 1 II 1925 roku znalazł się w Polsce. W latach 1926-1931 był rektorem Instytutu Misyjnego w Lub- 
w Pińsku. Dnia 23 I 1937 roku biskup Bukraba erygował przy kaplicy parafię pw. Matki Bożej Królowej Korony Polskiej. Jej terytorium objęło wschodnią część miasta, do ulicy Szeptyckiego. Liczba parafian wynosiła początkowo ponad 3000 wiernych. W piśmie z 22 I 1937 roku ordynariusz piński powierzył pełnienie obowiązków proboszcza (nie proboszcz) ks. Kohutnickiemu. Aktu przekazania parafii ks. Kohutnickiemu dokonał w imieniu biskupa dziekan baranowicki, przed którym, zgodnie z normami Kodeksu Prawa Kanonicznego (kanon 1406 par. 1, nr 7), złożył wyznanie wiary. Na samym początku funkcjonowania nowej parafii jej proboszcz winien sporządzić spis inwentarza parafialnego w trzech egzemplarzach: jeden dla archiwum parafii, drugi dla miejscowego dziekana i trzeci dla archiwum diecezjalnego w Pińsku. Erekcja nowego ośrodka duszpasterskiego zakończyła wieloletnie starania tamtejszych wiernych i pasterza diecezji o kolejną w tym mieście parafię. Odtąd miał nastąpić rozwój życia duchowego mieszkańców Baranowicz ${ }^{14}$.

Stan posiadania powstałej kolejnej parafii w Baranowiczach przedstawiał się dosyć skromnie leczy wystarczająco do sprawowania kultu i posługi pastoralnej dla tamtejszych wiernych.

Budynek: Pierwotna kaplica mieściła się w budynku mieszkalnym o wymiarach 20 metrów długi i 9 metrów szeroki, adaptowanym do celów kultowych. Kaplica posiadała zakrystię, babiniec i skarbiec. Budynek posiadał 12 okien (wysokość $1.5 \mathrm{~m}$ i szerokość $1 \mathrm{~m}$ ), drzwi drewniane, był pokryty blachą. Wnętrze kaplicy było otynkowane, zewnętrzne ściany były szalowane. Budynek został ubezpieczony. Przy kaplicy stała prowizoryczna dzwonnica. Do dyspozycji parafii służył budynek murowany o wymiarach 5 na 6 metrów.

Wnętrze kościoła: w kaplicy znajdował się jeden ołtarz główny drewniany, w którym mieściło się tabernakulum zamykane na klucz. W ołtarzu znajdował się obraz Matki Bożej, nieznanego malarza. Mensa ołtarzowa była drewniana. Ołtarzy bocznych nie było. $Z$ braku chrzcielnicy, wodę chrzcielną przechowywano w naczyniu szklanym. Słowo Boże głoszono od ołtarza. W kaplicy znajdowały się dwa konfesjonały, ławki drewniane, brak było chóru i organów, do liturgii służyło fisharmonium. Przed kaplicą stała figura Matki Bożej Niepokalanie Poczętej.

Zakrystia: posiadała dwoje drzwi zamykanych na klucz, okno okratowane, podłogę z desek. W niej mieściła się komoda z szufladami na paramenty kościelne i stół służący za kredencję. W zakrystii stał jeden klęcznik i dwie biblioteczki:

linie. W 1932 roku mianowany proboszczem parafii Szczytniki (dek. brzeski), na terenie diecezji pińskiej oraz wykładowca w pińskim Seminarium Duchownym. Pracownik kurii pińskiej, prałat papieski i kanonik kapituły pińskiej. W czasie II wojny światowej proboszcz parafii Chotów (dek. stołpecki). Pobity przez policję niemiecką, zmarł w 1944 roku w szpitali wskutek odniesionych obrażeń. Niech świadectwo nie będzie zapomniane. Losy Kościoła katolickiego na Białorusi w latach 1917-1953, red. R. Wierna, Grodno 200, s. 38-39.

${ }^{14}$ ADD, Zespół: Archiwum Parafii Baranowicze, Sygn. III/J/, Biskup Piński Kazimierz Bukraba do ks. Antoniego Kohutnickiego z 22 I 1937 (Num. 305/37), Wikariusz Generalny (sufragan Karol Niemira) do ks. A. Kohutnickiego z 23 I 1937 (L. 306/37) - Pińsk; Spis kościołów i duchowieństwa diecezji pińskiej $w$ R. P. 1937, Pińsk 1937, s. 50. 
jedna dla potrzeb tercjarzy a druga do przechowywania dokumentów (m.in. o odpustach nadawanych).

Cmentarz kościelny: teren cmentarza o powierzchni $3600 \mathrm{~m}$ c ogrodzony byů drewnianymi sztachetami z bramŕ o murowanych filarach, przy kaýdym filarze po dwie furtki dla pieszych. Część frontowa ołtarza biegła od ulicy Rynkowej. Cmentarz porośnięty był sosnami, brzozami i innym drzewostanem.

Archiwum parafialne zostało zapoczątkowane. Parafia nie posiadała żadnego beneficjum.

Na terenie parafii działały organizacje: Stowarzyszenie Akcji Katolickiej Kobiet, Młodzieży Żeńskiej i Męskiej, Krucjata Eucharystyczna. Na terenie parafii mieściły się dwie szkoły i ochronka.

Parafia świętowała swoje odpusty: 3 maja i na uroczystość Serca Pana Jezusa. Kaplic żadnych nie ma.

Budowie nowego kościoła nadal przeciwstawiały się niektóre miejscowe ,jednostki przesiąknięte bolszewizmem i wschodnim bezbożnictwem” - używając słownictwa proboszcza ks. Kohutnickiego. Do nich należeli m.in. Adolf Szczuka (zamieszkały przy ul. Kleckiej 5 w Baranowiczach), powszechnie zwany „Szczupakiem”, dalej Apanasiuk, Dubas i kilku mniej znanych z nazwiska. Jednak silna była grupa miejscowych kolejarzy, popierających inicjatywę budowy kościoła, którym przewodniczyli panowie: Tratkiewicz, Jasionowski i Zatorski. Szczególnym przywiązaniem do Kościoła i życzliwością dla nowego proboszcza odznaczał się pan Wasilewski.

Pełniąc obowiązki proboszcza parafii w Baranowiczach, ks. Kohutnicki zapoczątkował prowadzenie ksiąg metrykalnych: urodzonych, zaślubionych, zmarłych i nawróconych, co było zwyczajną praktyką i obowiązkiem proboszcza parafii. Do dziś zachowały się księgi metrykalne zapoczątkowane przez ks. Kohutnickiego, które były kontynuowane przez jego następców, z wyjątkiem księgi zmarłych ${ }^{15}$. Dysponujemy także dzisiaj księgą metrykalną ochrzczonych z późniejszych lat, także powojennych, a jest nią: Księga chrztów parafii Królowej Kor. Polskiej Baranowicze Poleskie od 1944 r. ${ }^{16}$

Ks. Kohutnicki niedługo pełnił obowiązki proboszcza parafii Królowej Korony Polskiej. Przed złożeniem urzędu dnia 2 V 1938 roku w Baranowiczach sporządził: Inwentarz parafialnego rzymsko-katolickiego kościoła w Baranowiczach Poleskich. Sporządzony dnia 2 maja 1938 roku przez Księdza Antoniego Kohutnickiego Prob., par. Królowej Korony Polskiej ${ }^{17}$, dzięki któremu poznamy wyposażenie parafii jakie zdołał pozyskać jej pierwszy proboszcz, a to ukazuje także jego troskę o Dom Boży, sprawowanie liturgii i pracę pastoralną.

Wyposażenie nowego ośrodka duszpasterskiego stanowiły:

${ }^{15}$ ADD, Zespół: Archiwum Parafii Baranowicze: Księga chrztów parafii Królowej Korony Polski w Baranowiczach Poleskich 1936-1943, Księga ślubów parafii Królowej Korony Polski w Baranowiczach 1937-1946 (Sygn. ), Liber Confirmatorium rzymsko-katolickiego kościoła parafialnego M.B. Królowej Korony Polski w Baranowiczach (Sygn. I/C/), Księga ochrzczonych parafii M.B. Królowej Korony Polskiej w Baranowiczach od 1944 do lutego 1946 (Sygn. I/B/2/).

${ }^{16}$ ADD, Zespół: Akta Parafii Baranowicze, Sygn. I/B/2.

${ }^{17}$ ADD, Zespół: Archiwum Parafii Baranowicze, Sygn. III/I/2. 


\begin{tabular}{|c|c|c|c|c|c|c|c|}
\hline \multirow{3}{*}{ L.p. } & \multirow{3}{*}{ Nazwa przedmiotu } & \multirow{3}{*}{ Ilość } & \multicolumn{4}{|c|}{ Wartość } & \multirow[t]{3}{*}{ Uwagi } \\
\hline & & & \multicolumn{2}{|c|}{ pojedyn. } & \multicolumn{2}{|c|}{ razem } & \\
\hline & & & zł. & gr. & zł. & gr. & \\
\hline 1 & Kościół & 1 & 4500 & - & 4500 & - & \\
\hline 2 & Ołtarz & 1 & 150 & - & 150 & - & \\
\hline 3 & Tabernakulum & 1 & 25 & - & 25 & - & \\
\hline 4 & Obraz w ołtarzu & 1 & 25 & - & 25 & - & \\
\hline 5 & 14 obrazów st. męki Pańskiej & 14 & 5 & - & 70 & - & \\
\hline 6 & Obraz Chrystusa w koronie cierniowej & 1 & 15 & - & 15 & - & \\
\hline 7 & Obraz N. S. J. & 1 & 40 & - & 40 & - & \\
\hline 8 & Obraz św. Antoniego & 1 & 30 & - & 30 & - & \\
\hline 9 & Naczynie na wodę do chrztu & 1 & 4 & - & 4 & - & słoik \\
\hline 10 & Konfesjonał & 1 & 25 & - & 25 & - & \\
\hline 11 & Lawek & 12 & 15 & - & 180 & - & +3 lawki \\
\hline 12 & Harmonium & 1 & 600 & - & 600 & - & \\
\hline 13 & Figura M. Bożej & 1 & 270 & - & 270 & - & (na cmentarzu) \\
\hline 14 & Figura Zmartwychwstania Pańskiego & 1 & 45 & - & 45 & - & \\
\hline 15 & Figura Dz. Jezus & 1 & 19 & - & 19 & - & (żłóbek) \\
\hline 16 & Figura M. Bożej & 1 & 50 & - & 50 & - & \\
\hline 17 & Komoda & 1 & 30 & - & 30 & - & \\
\hline 18 & Klęczniki & 2 & 10 & - & 20 & - & \\
\hline 19 & Stoły & 2 & 10 & - & 20 & - & $\begin{array}{c}\text { (1 na plebani } \\
\text { i } 1 \text { w zakrystii) }\end{array}$ \\
\hline 20 & Lawaterz & 1 & 5 & - & 5 & - & \\
\hline 21 & Tablica praep. ad Miss. & 1 & 8 & - & 8 & - & \\
\hline 22 & Tablica dokument terc. & 1 & 3 & - & 3 & - & \\
\hline 23 & Tablica dokument odp. & 1 & 3 & - & 3 & - & \\
\hline 24 & Tablica porządek nabożeństw & 1 & 3 & - & 3 & - & \\
\hline 25 & Tablice ołtarzowe & 3 & 3 & - & 9 & - & \\
\hline 26 & Grób Chrystusowy & 1 & 25 & - & 25 & - & \\
\hline 27 & Monstrancja & 1 & 360 & - & 360 & - & \\
\hline 28 & Kielich srebrny & 1 & 270 & - & 270 & - & \\
\hline 29 & Kielich miedziany & 1 & & & & & (ofiara) \\
\hline 30 & Patena srebrna & & & & & & \\
\hline 31 & Patena miedziana & & & & & & \\
\hline 32 & Patena do chorych srebrna & 1 & 56 & - & 56 & - & \\
\hline 33 & Naczynko do Olejów św. chorych & 1 & 20 & - & 10 & - & \\
\hline 34 & Naczynko do Olejów św. chrzcielnych & 1 & 18 & - & 18 & - & \\
\hline 35 & Kubek do chrztu & 1 & 4 & - & 4 & - & \\
\hline 36 & Lichtarze miedziane pogrzebowe & 6 & 15 & - & 90 & - & \\
\hline 37 & $\begin{array}{l}\text { Lichtarzy drewnianych wielkich } \\
\text { do katafalku }\end{array}$ & 6 & & & 20 & - & (4 tylko) \\
\hline 38 & Lichtarz wielki do paschału & 1 & 10 & - & 10 & - & \\
\hline 39 & Lichtarzyków drewnianych & 2 & 2 & - & 4 & - & \\
\hline 40 & Lichtarze małe srebrne & 2 & 7 & 50 & 15 & - & \\
\hline 41 & Lichtarzy małych cynowych & 4 & 1 & 50 & 6 & - & \\
\hline 42 & Łódka & 1 & 5 & - & 5 & - & (nie ma) \\
\hline 43 & Lawaterz duży w zakrystii & 1 & 1 & - & 1 & - & \\
\hline
\end{tabular}




\begin{tabular}{|c|c|c|c|c|c|c|c|}
\hline 44 & Kropielnica & 1 & & & & & \\
\hline 45 & Lawaterz mały & & & & & & \\
\hline 46 & Dzwonki harmonijne & 1 & & & & & \\
\hline 47 & Dzwonek mały ręczny & 1 & 2 & - & 2 & - & \\
\hline 48 & Dzwonek przy zakrystii & 1 & & & & & \\
\hline 49 & Kapa czarna & 1 & & & & & \\
\hline 50 & Kapa biała & 1 & & & & & \\
\hline 51 & Kapa filetowa & 1 & & & & & \\
\hline 52 & Kapa zielona & 1 & & & & & \\
\hline 53 & Stuła & 7 & & & & & \\
\hline 54 & Alby białe & 4 & & & & & \\
\hline 55 & Humerały płócienne & 6 & & & & & + jeden \\
\hline 56 & Sznury lniane & 4 & & & & & (2 nie ma) \\
\hline 57 & Sznury bawełniane & 2 & & & & & \\
\hline 58 & Korporały & 14 & & & & & (minus dwa) \\
\hline 59 & Korporalików do Wiatyku & 12 & & & & & \\
\hline 60 & Palek & 6 & & & & & \\
\hline 61 & Puryfikaterzy & 18 & & & & & \\
\hline 62 & Ręczników do ołtarza & 6 & & & & & \\
\hline 63 & Ręczników dużych do wycierania rąk & 2 & & & & & \\
\hline 64 & Komże płócienne & 8 & & & & & \\
\hline 65 & Obrusy na ołtarz płócienne lniane & 4 & & & & & \\
\hline 66 & Komże dla chłopców & 4 & & & & & \\
\hline 67 & Nakrycia na ołtarz & 2 & & & & & \\
\hline 68 & Dywanów nowych & 2 & & & & & \\
\hline 69 & Dywan stary & 1 & & & & & \\
\hline 70 & Krzyż wielki dębowy & 1 & 20 & - & 20 & - & \\
\hline 71 & Krzyż mniejszy dębowy & 1 & 15 & - & 15 & - & \\
\hline 72 & Krzyż procesjonalny srebrny & 1 & 35 & - & 35 & - & \\
\hline 73 & Krzyż na tabernakulum & 1 & 5 & - & 5 & - & \\
\hline 74 & Krzyż w zakrystii & 1 & 3 & - & 3 & - & \\
\hline 75 & Fotek & 1 & 25 & - & 25 & - & \\
\hline 76 & Pulpit pod mszał & 1 & 20 & - & 20 & - & \\
\hline 77 & Pulpit na wielki tydzień & 1 & 15 & - & 15 & - & \\
\hline 78 & Skarbonka do kwesty po kościele & 1 & 2 & - & 2 & - & \\
\hline 79 & Skarbonka w babińcu & 1 & 2 & - & 2 & - & \\
\hline 80 & Katafalk & 1 & 40 & - & 40 & - & \\
\hline 81 & Baldachim & 1 & 120 & - & 120 & - & \\
\hline 83 & Poduszka pod mszał & 1 & 10 & - & 10 & - & \\
\hline 84 & Poduszka zapasowa & 1 & 10 & - & 10 & - & \\
\hline 85 & Ornat biały & 1 & & & & & \\
\hline 86 & \begin{tabular}{|l|} 
Ornat czarny \\
\end{tabular} & 1 & & & & & \\
\hline 87 & Ornat fioletowy & 1 & & & & & \\
\hline 88 & Ornat zielony & 1 & & & & & \\
\hline 89 & Welon (tuwalnia) & 2 & & & & & \\
\hline 90 & Sukienka na puszkę & 2 & & & & & \\
\hline 91 & Bursa dla chorych & 2 & & & & & \\
\hline
\end{tabular}




\begin{tabular}{|c|l|c|c|c|c|c|c|}
\hline 92 & Mszał nowy w ozdobnej oprawie & 1 & 120 & - & 120 & - & \\
\hline 93 & Mszał nowy żałobny & 1 & 22 & - & 22 & - & \\
\hline 94 & Ewangelia na niedziele i święta & 1 & 22 & - & 22 & - & \\
\hline 95 & $\begin{array}{l}\text { Wademekum do chorych nowe } \\
\text { wydanie w oprawie }\end{array}$ & 1 & & & & & \\
\hline 96 & $\begin{array}{l}\text { Księga urodzeń i chrztów od roku } \\
1937\end{array}$ & 1 & & & & & \\
\hline 97 & Księga ślubów od roku 1937 & 1 & & & & & \\
\hline 98 & Księga zgonu od roku 1937 & 1 & & & & & \\
\hline 100 & Liber conversorum od 1937 & 1 & & & & & \\
\hline 101 & Raptularz urodzeń & 1 & & & & & \\
\hline 102 & Raptularz zgonu & 1 & & & & & \\
\hline 103 & Księga zapowiedzi & 1 & & & & & \\
\hline 104 & Dziennik korespondencyjny & 1 & & & & & \\
\hline 105 & Dzwony pry & 1 & & & & & \\
\hline 106 & $\begin{array}{l}\text { Dokument erekcji par. załączony przy } \\
\text { nin. książce }\end{array}$ & 1 & & & & & \\
\hline 107 & Księga inwentarza & 1 & & & & & \\
\hline 108 & Księga rachunków & & & & & & \\
\hline 109 & Pieczęcie kościelne & & & & & & \\
\hline 110 & $\begin{array}{l}\text { Pieczęć okrąła parafialna } \\
\text { Z wizerunkiem M.B. (w jęz. polskim) }\end{array}$ & & & & & & \\
\hline 111 & Pieczęć kwadratowa (nagłówkowa) & 1 & & & & & \\
\hline 112 & Pieczęć z napisem ,proboszcz par.” & 1 & & & & & \\
\hline 113 & Pieczęć Komitetu Budowy Kościoła & 1 & & & & & \\
\hline
\end{tabular}

Po odejściu z Baranowicz ks. Kohutnickiego, pan Adolf Szczuka zamieszkały przy ul. Kleckiej 5 w Baranowiczach zapoznał się z treścią księgi inwentarzowej, sporządzonej przez odchodzącego przed rokiem proboszcza. W części poświęconej historii kościoła znalazł następujący zapis: „Największym nieszczęściem tej dzielnicy (nb. Nowych Baranowicz) miasta, jak i przeszkodą w pracy budowy lepszego jutra w parafii to, jak i wszędzie znalazły się jednostki przesiąknięte duchem bolszewickim i wschodnim bezbożnictwem. Aby przekazać potomności imiona tych ludzi godnych potępienia należy wymienić w pierwszym rzędzie Adolfa Szczuka powszechnie zwanego „Szczupakiem”, Apanasiuka, Dubasa i kilku innych mniej znanych i szkodliwych itd.”. Czując się powyższym zapisem wielce pokrzywdzony, wymieniony Szczuka zwrócił się do ordynariusza diecezji o wydanie zarządzenia w celu zrehabilitowania go i usunięcia niesłusznych - jego zdaniem - zarzutów z księgi parafialnej.

Na swoją obronę wyjaśnił ordynariuszowi, że już w 1910 roku należał do istniejącego wówczas komitetu budowy kościoła w Baranowiczach (pw. Podwyższenia Swiętego Krzyża), w którym to komitecie poczynił wiele starań i prac oraz był członkiem delegacji do księdza arcybiskupa Wincentego Kluczyńskiego ${ }^{18}$

${ }^{18}$ Kluczyński Wincenty, ur. 30 IX 1847 w Szarkowszczyźnie, zm. 10 II 1917 na Krymie. Filozofię i teologię studiował w seminarium duchownym w Wilnie i Akademii Duchownej w Petersburgu. Święcenia kapłańskie przyjął w 1871 w Kownie, wykładowca w seminarium duchownym w Wilnie, kanonik honorowy kapituły wileńskiej (1883) i inspektor seminarium duchownego, prałat 
w Petersburgu o przydzielenie do Baranowicz kapłana. W czasie organizowania kolejnej parafii $\mathrm{w}$ Baranowiczach był jednym z inicjatorów powstania kaplicy, udzielił własnego lokalu na zebranie parafian w sprawie zakupu domu na kaplicę, dołożył wiele starań przy urządzaniu kaplicy, brał czynny udział w imprezach i kwestach na rzecz kaplicy. Wraz z żoną zorganizował zbiórkę na baldachim, chorągiew, których uszycie i haftowanie wykonał wspólnie z żoną oraz organizował zbiórki na krzyż do procesji, paschał, wykonał dekorację do grobu Chrystusa. Na potwierdzenie powyższych słów powoływał na świadka ks. Jana Borysiuka, dziekana w Baranowiczach ${ }^{19}$.

Po zapoznaniu się z treścią pisma, wikariusz generalny, sufragan piński Karol Niemir przesłał dnia 1 VIII 1939 roku do dziekana baranowickiego upoważnienie, ,aby ustęp zawierający napastliwe słowa wypisane pod adresem p. Adolfa Szczuki, jeżeli są niezgodne z prawdą skreślić i zrobić stosowne omówienie powiadamiając o tem petenta”. Dnia 10 września tego roku proboszcz parafii Królowej Korony Polskiej - ks. Bronisław Wieliczko ${ }^{20}$ przesłał do dziekana w Baranowiczach informację, że ustęp o którym mowa, został skreślony z historii Kościoła tutejszego a nazwisko wymazane ${ }^{21}$.

Po ks. Antonim Kohutnickim obowiązki proboszcza parafii Królowej Korony Polskiej przejął dnia 9 V 1937 roku ks. Czesław Fedorowicz ${ }^{22}$. Dwa lata później

kapituły wileńskiej. Dla pomocy w katechizacji utworzył w 1889 bezhabitowe zgromadzenie sióstr od Aniołów i kierował jego działalnością. Papież Pius X pod naciskiem rządu rosyjskiego mianował go w 1910 roku arcybiskupem mohylewskim i administratorem apostolskim diecezji mińskiej, która wówczas podlegała arcybiskupowi mohylewskiemu. Zwierzchnictwo nad diecezją wiązało się $\mathrm{z}$ ustawiczną walką z departamentem obcych wyznań oraz z ministerstwem oświaty. Kluczyński dążył do zarejestrowania osób, które w latach 1905-1907 przeszły z prawosławia na katolicyzm, zwłaszcza na Mińszczyźnie. Występował w obronie księży represjonowanych przez władze carskie. W 1911 roku wspólnie z biskupami swojej prowincji wydał list w sprawie nieskrępowania przez carat działalności Kościoła. Domagał się budowania kościołów i kaplic dla robotników katolickich zesłanych na Syberię, bronił języka polskiego w liturgii i praw Kościoła w sprawie małżeństw mieszanych. Trudności z rządem rosyjskim doprowadziły do złożenia przez niego 11 XI 1913 roku rezygnacji z urzędu. Rezygnację Stolica Apostolska przyjęła w 1914 roku. Rządy diecezją objął bp Jan Cieplak. S. Tylus, Kluczyński Wincenty, EK, t. 9, Lublin 2002, k. 169.

${ }^{19}$ Adolf Szczuka do Ordynariusza Diecezji Pińskiej z 5 VI 1939 r.- Baranowicze, w: Księga inwentarzowa parafii Baranowicze 1939 r., ADD, Zespół: Archiwum Parafii Baranowicze, Sygn. $\mathrm{III} / \mathrm{J} /$.

${ }^{20}$ Ks. Bronisław Wieliczko, urodził się 13 XI 1903 roku w Wojdziewiczach koło Wołożyna (obecnie Białoruś). Święcenia kapłańskie otrzymał w Pińsku 15 IV 1933 roku, następnie pracował w Pińsku (1933-1934). Tuż przed wojną i w czasie II wojny światowej duszpasterzował w Baranowiczach aż do momentu ewakuacji. Na Ziemie Odzyskane przybył 25 XI 1949 roku. Duszpasterzował jako proboszcz w parafii Lipka Krajeńska w diecezji gorzowskiej. W. Urban, Duszpasterska siejba kapłanów-repatriantów na ziemiach odzyskanych $w$ latach 1945-1970, Wrocław 1972, s. 111.

${ }^{21}$ Proboszcz parafii Królowej Korony Polskiej ks. Bronisław Wieliczko do ks. Jana Borysiuka (dziekana baranowickiego) z 10 IX 1939 r.- Baranowicze, w: Księga inwentarzowa parafii Baranowicze 1939 r., ADD, Zespół: Archiwum Parafii Baranowicze, Sygn. III/J/.

${ }^{22}$ Fedorowicz Czesław, syn Antoniego, ur. 20 (lub 12) XII 1891 na Podolu, ukończył gimnazjum kamienieckie, w październiku 1910 roku wstąpił do seminarium duchownego w Żytomierzu, 
dnia 11 V 1939 roku zrzekł się probostwa baranowickiego i opuścił diecezję pińską. Po otrzymaniu odmowy od biskupa podlaskiego o przyjęcie go do tej diecezji, po wybuchu II wojny światowej wyjechał do Francji, gdzie podjął duszpasterstwo Polaków w Sallaumines w Pas-de-Calais. Zmarł w maju 1940 roku na skutek ran odniesionych w czasie działań wojennych.

W czasie dwóch lat jego pracy duszpasterskiej i proboszczowania w Baranowiczach tamtejsza parafia została wyposażona w dodatkowe przedmioty i paramenty liturgiczne:

\begin{tabular}{|c|c|c|c|c|c|c|c|}
\hline \multirow{3}{*}{ L.p. } & \multirow{3}{*}{ Nazwa przedmiotu } & \multirow{3}{*}{ Ilość } & \multicolumn{4}{|c|}{ Wartość } & \multirow[t]{3}{*}{ Uwagi } \\
\hline & & & \multicolumn{2}{|c|}{ pojedyn } & \multicolumn{2}{|c|}{ razem } & \\
\hline & & & zł. & gr. & zł. & gr. & \\
\hline 114 & Ławka dla księży & 1 & 20. & - & 20. & - & \\
\hline 115 & Pierścionek złoty $\mathrm{z}$ ametystem & 1 & & & & & \\
\hline 116 & Dwie obrączki ślubne, złote & 2 & & & & & \\
\hline 117 & Kociołek i kropidło & & & & & & \\
\hline 118 & Kadzielnica i łódka & & & & & & \\
\hline 119 & Kustodium złocone (monstrancja) & 1 & 36. & - & 36. & - & \\
\hline 120 & Klęcznik & 1 & & & & & \\
\hline 121 & Półklęcznik & 1 & & & & & \\
\hline 122 & Ornat fioletowy & 1 & & & & & \\
\hline 123 & Stuła żałobna & 1 & & & & & \\
\hline 124 & Stuła czerwona & 1 & & & & & \\
\hline 125 & Obrus & 1 & & & & & \\
\hline
\end{tabular}

po 4 kursie skierowany został na dalsze studia do Akademii Duchownej w Petersburgu (1914-1917), którą ukończył ze stopniem kandydata prawa kanonicznego. Tam otrzymał 15 VI 1917 roku święcenia kapłańskie z rąk bpa Jana Cieplaka. Ordynariusz łucko-żytomierski bp Ignacy Dubowski mianował go kapelanem szkół w Białej Cerkwii (dek. Kijów), od 6 VIII 1918 roku był wikariuszem w Płoskirowie. W lutym 1919 roku bp kamieniecki pozwolił mu wyjechać na Uniwersytet Lubelski dla dokończenia studiów. Po przekroczeniu zielonej granicy dotarł do Lublina. Po uzyskaniu tytułu magistra prawa kanonicznego powrócił na Podole. W 1920 mianowany promotorem sprawiedliwości i obrońcą węzła małżeńskiego w sądzie biskupim w Kamieńcu Podolskim, do 1921 dziekan w Mohylewie Podolskim. Następnie wyjechał na prowincję i pracował w parafiach Wójtowce, Pików, Śnitków i od listopada 1921 był dziekanem Lityńskim, od 1923 roku przeszedł do parafii Brahiłów (dek. winnicki), w latach 1925-26 pracował w Gniewaniu. Otwarcie występował przeciw władzy radzieckiej, za co już jesienią 1922 roku trafił do więzienia w Winnicy, ponownie aresztowany w 1926 i skazany (18 IX) na 3 lata łagrów, zesłany na Sołówki. Po roku powrócił do Winnicy i tu oskarżony o kierowanie w parafii gniewińskiej „kontrrewolucyjną organizacją”, skazany został wyrokiem sądu winnickiego z 13 II 1929 roku na karę śmierci, zamienioną na 10 lat więzienia (łagrów). Przebywał w więzieniu na Chłodnej Górze w Charkowie, Jarosławiu nad Wołgą skąd w połowie września 1932 roku powrócił do Polski w wyniku wymiany grupy 51więźniów politycznych (w tym 18 księży). Osiadł w diecezji pińskiej, od 1933 proboszcz parafii Starojelnia, rektor kościołów w Łopusznej i Walówce (dek. nowogródzki), następnie w Baranowiczach. Zmarł na skutek odniesionych ran w 1940 we Francji. Do końca pozostał kapłanem diecezji kamienieckiej. Wymieniany także pod nazwiskiem Fiedorowicz. Dzwonkowski, Losy duchowieństwa katolickiego w ZSRR 1917-1939, s. 226-227;W. Rosowski, Dzieje rzymskokatolickiej diecezji kamienieckiej w latach 1918-1941, Lublin 2008, s. 102, 128, 158-161, 187-188, 243-244. 


\begin{tabular}{|c|c|c|c|c|c|c|c|}
\hline 126 & Humerały & 8 & & & & & -1 \\
\hline 127 & Palki & 4 & & & & & \\
\hline 128 & Korporały & 12 & & & & & -11 \\
\hline 129 & Puryfikaterze & 19 & & & & & \\
\hline 130 & Ręczniczki & 2 & & & & & \\
\hline 131 & Kołnierzyki (do stuły) & 3 & & & & & \\
\hline 132 & Figura Serca Jezusa & 1 & & & & & \\
\hline 133 & Obraz (oleodruk) P.J. w ogrójcu & 1 & 50. & - & 50. & - & \\
\hline 134 & Portret Ojca św. Piusa XI & 1 & 12 & - & 12 & - & \\
\hline 135 & Obraz Królowej Jadwigi & 1 & 19. & - & 19. & - & \\
\hline 136 & Konopeum zielone & 1 & & & & & \\
\hline 137 & Konopeum filetowe & 1 & & & & & \\
\hline 138 & Pas do dzwonka & 1 & & & & & \\
\hline 139 & $\begin{array}{l}\text { Dwie półeczki pod figurę M.B. } \\
\text { i Serca J. }\end{array}$ & 2 & & & & & \\
\hline 140 & $\begin{array}{l}\text { Dwie chorągwie żałobne } \\
\text { z pokrowcami }\end{array}$ & 2 & 50. & - & 50. & - & \\
\hline 141 & Zegar ścienny okrągły & 1 & 37. & - & 37. & - & \\
\hline 142 & Lustro w zakrystii & 1 & 7. & 50 & 7. & 50 & \\
\hline 143 & $\begin{array}{l}\text { Dwie czarne pelerynki dla } \\
\text { chłopców }\end{array}$ & 2 & & & & & \\
\hline 144 & $\begin{array}{l}\text { Dwie czerwone pelerynki dla } \\
\text { chłopców }\end{array}$ & 2 & & & & & \\
\hline 145 & $\begin{array}{l}\text { Dwie spódniczki czerwone dla } \\
\text { chłopców }\end{array}$ & 2 & & & & & \\
\hline 146 & Dwa sztandary narodowe & 2 & 10. & - & 10. & - & \\
\hline 147 & Rytuał & 1 & 36. & - & 36. & - & \\
\hline 148 & Rytuał mały & 1 & 2 & 20 & 2 & 20 & \\
\hline 149 & Śpiewniki kościelne Siedleckiego & 2 & 3 & 60 & 7 & 20 & \\
\hline 150 & Kancjonał & 1 & 18. & - & 18. & - & \\
\hline 151 & Wielki Tydzień & 1 & 2. & - & 2. & - & \\
\hline 152 & Liber Usualis & 1 & 12. & - & 12. & - & \\
\hline 153 & $\begin{array}{l}\text { Ks. Stanisław Łukomski, } \\
\text { Konkordat }\end{array}$ & 1 & & & & & \\
\hline 154 & $\begin{array}{l}\text { Pierwszy Synod Diecezjalny } \\
\text { Piński }\end{array}$ & 1 & & & & & \\
\hline 155 & $\begin{array}{l}\text { Primum Concilium Plenarium } \\
\text { Polonicum (broszura) }\end{array}$ & 1 & & & & & \\
\hline 156 & $\begin{array}{l}\text { Piński Przegląd Diecezjalny od r. } \\
1933 \text { do } 1937 \text { włącznie } \\
\text { w oprawie }\end{array}$ & 1 & & & & & \\
\hline 157 & $\begin{array}{l}\text { Najnowsze przepisy o chowaniu } \\
\text { zmarłych }\end{array}$ & 1 & - & 35 & - & 35 & \\
\hline 158 & $\begin{array}{l}\text { Teczka z dokumentami } \\
\text { odnoszącymi się do nawróconych } \\
\text { i spraw małżeńskich (od } \\
\text { powstania parafii) }\end{array}$ & 1 & & & & & $\begin{array}{l}\text { Wszystkie trzy } \\
\text { teczki mają }\end{array}$ \\
\hline 159 & $\begin{array}{l}\text { Teczka zawierająca pisma Kurii } \\
\text { Biskupiej i inne za tenże czas }\end{array}$ & 1 & & & & & papiery wszyte \\
\hline 160 & Teczka z dowodami kasowymi & 1 & & & & & \\
\hline
\end{tabular}




\begin{tabular}{|c|c|c|c|c|c|c|}
\hline 161 & Stemple gumowe & 4 & - & - & 5. & 50 \\
\hline 162 & $\begin{array}{l}\text { Dom-plebania } 14.20 \text { na } 8.30 \\
\text { metrów, drewniany, na } \\
\text { podmurówce, kryty gontami, } \\
\text { piętrowy, } 10 \text { okien, z piwnicą } \\
\text { murowaną i przybudówką nad } \\
\text { nią, } 7 \text { pokoi i kuchnia z płytą } \\
\text { kaflową. Podłoga drewniana }\end{array}$ & 1 & 5000. & - & 5000. & - \\
\hline 163 & Drzewka gruszki & 4 & & & & \\
\hline 164 & Drzewka jabłoni & 12 & & & & \\
\hline 165 & Drzewka czereśni & 3 & & & & \\
\hline 166 & Drzewka wiśni & 30 & & & & \\
\hline 167 & Krzewy agrestu & 10 & & & & \\
\hline 168 & Krzewy porzeczek & 25 & & & & \\
\hline 169 & Śliwek & 5 & & & & \\
\hline 170 & $\begin{array}{l}\text { Chorągiew Krucjaty } \\
\text { Eucharystycznej }\end{array}$ & 1 & 150 & - & & \\
\hline 171 & Krzyż żałobny & 1 & & & & \\
\hline
\end{tabular}

Przedstawione powyżej stany inwentarza kościoła parafialnego Matki Bożej Królowej Korony Polskiej w Baranowiczach: stan przejęty po ks. Kohutnickim z 2 V 1938 roku i kolejny powiększony za okres proboszczowania ks. Fedorowicza z dnia 11 V 1939 roku dały nam możliwość opisania genezy powstania kolejnej parafii w tym mieście. Tym samym stan ten przejął tego samego dnia następca ks. Fedorowicza - ks. Bronisław Wieliczko, dotychczasowy prefekt szkół powszechnych i duszpasterz w parafii Matki Bożej Królowej Korony Polskiej, który w Baranowiczach przeżył II wojnę światową.

W nominacji ordynariusza pińskiego biskupa Kazimierza Bukraby dla ks. Kohutnickiego do „pełnienia obowiązków proboszcza” parafii Matki Bożej Królowej Korony Polskiej w Baranowiczach z dnia 22 I 1937 roku biskup polecił, aby został sporządzony dotychczasowy inwentarz powstającej parafii w trzech egzemplarzach: jeden dla archiwum parafialnego, drugi dla księdza dziekana baranowickiego przy parafii Podwyższenia Świętego Krzyża i trzeci dla archiwum diecezjalnego w Pińsku. Ks. Kohutnicki nie uczynił tego przy obejmowaniu w administrację parafii, a przynajmniej do dziś taki inwentarz się nie zachował. Natomiast obecnie dysponujemy dwoma egzemplarzami inwentarza sporządzonego przez ks. Kohutnickiego przy przekazywaniu parafii jego następcy, które posłużyły do niniejszego opracowania i do dziś mieszczą się w Archiwum Diecezjalnym w Drohiczynie. Jeden z tych egzemplarzy jest powiększony o okres jednego roku pracy jego następcy ks. Fedorowicza. 


\title{
THE BEGINNINGS OF THE MOTHER OF GOD, QUINN'S OF POLAND PARISH IN BARANOWICZE (POLESIE) BASED ON THE INVENTORY'S BOOK OF THE PARISH BARANOWICZE FROM 2 OF MAY 1938
}

\begin{abstract}
Summary
The Polish Borderland's town Baranowicze in the county Nowogród (now Bialorus) was developing with resilience from the beginning of the 20. century. The need of a new parish church in the city saw the local bishop, as well as the believers The second parish in the city, after the 1925 founded Hole Cross Exaltation's parish has been created 1936. It was the Mother of God Quinn's of Poland parish. It's pastor became fr. Antoni Kohutnicki. And soon replaced him fr. Czesław Fedorowicz. At that time has been established the Inventor's Book which is allowing to get knowledge of the beginnings of that parish.
\end{abstract}

